\title{
7 Access to social protection in Kenya
}

\author{
The role of micro-traders' \\ associations
}

Raphael Indimuli

\section{Introduction}

In Sub-Saharan Africa, micro-trading ${ }^{1}$ is the most visible form of occupation (Brown, 2006), accounting for an estimated 43 percent of all informal nonagricultural employment (Skinner, 2008). It is a source of livelihoods dominated by women traders (Chen, Roever \& Skinner, 2016). In Kenya, the sector falls under the Micro, Small, and Medium Enterprises (MSMEs), a sector comprising of licensed and unlicensed businesses. The vast majority ( 93.3 percent) of the unlicensed businesses are micro, engaging less than ten employees and having an annual turnover of less than Kenya Shilling (KES) 50,000 or an equivalent of US dollar (USD) 494.1. ${ }^{2}$ Of the 18 sub-sectors within the MSME sector, wholesale and retail trade is the largest sub-sector (62.9 percent) due to low entry barriers. The sub-sector accounts for more than half (53 percent) of informal employment and contributes about 22.8 percent to Kenya's Gross Domestic Product (KNBS, 2016).

Despite the contribution of IWs to Kenya's economy and to employment creation across much of SSA, research on social protection reveals that most IWs in Africa lack social protection (ILO, 2017). The micro-traders who are the focus of this chapter work under deplorable conditions (Mitullah, 2003) without sanitation, social protection such as sick leave, paid leave, and maternity benefits. They work long hours, and their incomes are low and irregular. Their environment makes them vulnerable to ill health while inadequate incomes limit their ability to accumulate savings (and invest in assets) and to take up formal social protection products such as health insurance and pensions (Skinner, 2008; Chen, Roever \& Skinner, 2016).

Recent research also reveals that micro-traders in developing cities are subjected to endless harassment from city officials (Chen, Roever \& Skinner, 2016). Scholars (Lindell, 2010) point out that several IW associations have emerged to articulate their grievances and claim rights to work in public spaces. However, the literature on IWs and on social protection gives little attention on the possible link between social protection and IWs associations. Social protection include all measures, formal and informal that seek to provide relief from deprivation such as resource transfers in cash or in kind (protective measures); measures that seek to avert deprivation such as health insurance and pensions (preventive measures); 


\section{Raphael Indimuli}

measures that seek to improve real incomes and enhance capabilities such as credit schemes (promotive measures); and measures that seek to address issues of social equity and exclusion such as collective action (transformative measures) (Devereux \& Sabates-Wheeler, 2004). This chapter adopts Devereux and Sabates Wheelers (2004) framework to generate new knowledge on informal trader associations and their potential for enabling access to both formal and informal social protection measures in Kenya. However, it does not address protective measures since most IW associations do not offer this form of social protection.

This chapter uses empirical data collected from a combination of quantitative and qualitative methods, notably: a survey, Focus Group Discussions (FGD) and Key Informant Interviews (KIIs). It draws data from a survey that was conducted between April 2018 and December 2018 which interviewed 231 micro-traders in Nairobi and Kisumu. Three quarters (73.5 percent) of the survey interviews were sampled geographically, while the remaining quarter (26.5 percent) was sampled through a variety of traders' associations. The survey covered vulnerable groups of micro-traders, including traders who do not have fixed locations (mobile traders) and those traders without permanent or fixed structures such as stalls. Three types of micro-traders were identified: paid workers, own-account workers, and micro-enterprise owners with a maximum of two employees. The KIIs and FGDs were conducted between October 2018 and December 2019. A total of five FGDs were conducted with members of associations, while a total of 11 KIIs were conducted with leaders of those associations.

All economic activities in Kenya, including those of IWs, are governed by the state. The Kenyan Constitution provides for two levels of governance: the national level and the county level. At the national level, national policies and legislation recognize the contribution of IWs to the economy. This recognition dates back to 1972 when the International Labour Organization (ILO) conducted a study on employment and incomes in Kenya (ILO, 1972). Since 1972 to date, several policies have been introduced to address challenges associated with informality. These policies use terms like 'jua kali' 3 sector, informal sector, small-scale sector, and SME sector to denote 'informality'. Sessional Paper No. 2 of 1992 on "Small Enterprise and Jua-kali Development" was a pioneer policy exclusive to the sector. The policy defined "small enterprise" as an enterprise employing between 1 and 50 employees (ROK, 1992). Later, the Sessional Paper No. 2 of 2005 on "Development of Micro and Small enterprises for wealth and employment creation" was developed to address issues that prevent micro and small businesses from formalizing - such as registration, taxation, and licensing (ROK, 2005).

The MSE Act of 2012 is the first comprehensive law that is specific on informal actors. It provides for MSEs and establishes structures like the Micro and Small Enterprise Authority (MSEA) whose main function is to govern informal actors as well as the MSE Fund aimed at offering affordable finance to SMEs. Informal workers are represented on the board of MSEA, and its structures ${ }^{4}$ provide a platform for IWs to participate in the making of decisions that affect their work sites. Furthermore, a draft bill on Street Vendors Protection of Livelihood Bill (ROK, 
2019) was at the Senate with the object of granting rights to traders to engage in micro-trading in designated areas without harassment from city officials. It proposes the creation of a Hawkers and Street Vendors Authority (HSVA) whose task will be to manage the affairs of hawkers and street traders in Kenya.

Governance of micro-trading falls directly under city authorities (Skinner, 2008). The cities of Nairobi and Kisumu covered in this analysis are major cities in Kenya. Nairobi is the capital and largest city, while Kisumu, which is an inland port city, is the third largest urban centre. Cities, under the Urban Areas and Cities (UAC) Act of 2011, are to be governed and managed by County Governments with the help of Urban Boards (NCLR, 2019). County Governments require all micro-traders under their jurisdiction to apply for licenses or permits (KNBS, 2016). Application for licenses requires micro-traders to indicate trade location and indicate physical address, which is not possible for mobile traders. City authorities also expect traders to renew their license every year. Yet, most traders operate without it (KNBS, 2016). Some scholars (Racaud, Kago \& Owuor, 2018) argue that the policy environment in Kenya discourages traders from acquiring licenses because acquisition of a license does not guarantee that city authorities will not evict them. Racaud, Kago, and Owuor further argue that ambiguity in policy and practices leads to conflict between city authorities and traders. However, in the past few years, County Governments of Nairobi and Kisumu have shown more tolerance for micro-traders' activities. For instance, in Nairobi, the County government permits micro-traders to transact business without licenses in the Central Business District (CBD) on specific days or times (i.e. evenings) or at designated locations. The more tolerant atmosphere in Nairobi stems from the public statement issued by County Governor of Nairobi in 2017 abolishing collection of fees from 'mama mbogas' (Swahili term for female vegetable vendors) (DN, 2017). The Governor argued that abolishing the fee was a fulfilment of one of his campaign promises. In Kisumu, micro-traders are permitted to transact businesses on designated streets within the CBD, and most pay a trading fee to city officials as discussed later.

How informal workers are treated can be linked to perceptions of informal work by stakeholders, including the state. While there is no universally accepted definition or description of informality, the ILO, a global body that promotes the decent work agenda which includes right to social protection, describes informality as all economic activities by workers and economic units that are not covered, or not adequately covered, by formal arrangements in law or in practice (ILO, 2002). In Kenya, informality tends to be understood from an enterprise point of view, as unlicensed or unregistered enterprises (KNBS, 2016). Informality in policy documents is referred to by terms such as informal sector, jua kali sector, and the SME sector (ROK, 1992, 2005). Amidst these interpretations, it was necessary to find out from micro-traders how they perceive themselves. Discussions with micro-traders revealed that most perceived themselves as informal using various phrases like "we are "jua kali", "we are harassed by city officials", "we do not have a salary", "we do not have contracts", "we lack formal benefits e.g. health insurance and pensions", among others. Evidently, 
these quotes illustrate that the view of informality relates to location of operation, taxation, registration, condition of work, and the lack of social and legal protection. While the term 'workers' is used, it is important to note that most micro-traders did not perceive themselves as workers per se but as entrepreneurs or businesspersons. This view is also reflected in national policies that interpret informal traders as the self-employed and as people operating or employed in unlicensed or unregistered enterprises (KNBS, 2016).

The remainder of this chapter is organized in the following way: it commences by a section on 'socio-economic characteristics' which provides a detailed description of Kenyan micro-traders by focusing on demographic, social and economic features, and discusses key features of their work. It is followed by a section on 'micro-trader challenges' which briefly outlines the challenges in micro-trade to establish the need for social protection, and a section outlining the role and challenges of trader associations and provides a link between trader associations and formal insurance. Thereafter, a discussion section follows which compares members of associations with non-members and micro-traders enrolled in formal insurance schemes with the non-enrolled. Last, concluding remarks are made in conclusion section.

\section{Socio-economic characteristics of micro-traders}

Demographic characteristics have an influence on the uptake of formal insurance and/or enrolment in associations. Table 7.1 presents a set of worker characteristics relevant for understanding such relations. The full sample count is 223 workers, out of which 57 percent were sampled in Nairobi and 43 percent from Kisumu.

\section{Demographic characteristics}

Table 7.1 shows that almost half of micro-traders belong to an association, although some belong to more than one. Region-wise, more than half of sampled traders in Kisumu are members of associations compared to 43 percent in Nairobi. In terms of formal health insurance coverage, 39 percent of micro-traders have either their own cover or through their spouse. Interestingly, this is higher than the 2015/2016 Kenya Integrated Household Budget Survey (KIHBS), where 19 percent of the population, at the national level, had health insurance (KNBS, 2018). The dominant health insurance ( 93.3 percent) identified in the KIHBS report (also in our study as we shall see later) is the National Health Insurance Fund (NHIF) cover. The KIHBS report reveals urban populations as having a higher share of health insurance (29.2 percent) than rural populations (13.3 percent): the share of population with health insurance cover is even higher for Nairobi (40.7 percent) compared to Kisumu (27 percent). This finding seems to be in line with our finding on Nairobi (4l percent), but, for Kisumu, our findings are much lower (36 percent). 
Table 7.1 Key worker characteristics

\begin{tabular}{lrrrrrr}
\hline & All & \multicolumn{3}{c}{ Nairobi } & Kisumu \\
\cline { 2 - 7 } & Mean & \multicolumn{1}{c}{ SD } & Mean & SD & Mean & SD \\
\hline Association membership* & 0.47 & 0.50 & 0.43 & 0.50 & 0.53 & 0.50 \\
Formal SI (health/pension) & 0.27 & 0.45 & 0.26 & 0.44 & 0.29 & 0.46 \\
$\quad$ enrolment & & & & & & \\
Heath insurance coverage & 0.39 & 0.49 & 0.41 & 0.49 & 0.36 & 0.48 \\
Gender (male = 1) & 0.45 & 0.50 & 0.46 & 0.50 & 0.43 & 0.50 \\
Age & 36.65 & 10.92 & 36.33 & 11.76 & 37.05 & 9.76 \\
Married & 0.63 & 0.48 & 0.56 & 0.50 & 0.72 & 0.45 \\
Local born & 0.28 & 0.45 & 0.18 & 0.39 & 0.41 & 0.49 \\
Mean daily earnings** (USD) & 11.12 & 11.61 & 8.70 & 7.05 & 14.27 & 15.14 \\
Assets (house and/or land) & 0.23 & 0.42 & 0.17 & 0.37 & 0.32 & 0.47 \\
Primary incomplete & 0.16 & 0.37 & 0.12 & 0.33 & 0.22 & 0.41 \\
Primary complete & 0.40 & 0.49 & 0.44 & 0.50 & 0.35 & 0.48 \\
Secondary and above & 0.43 & 0.50 & 0.44 & 0.50 & 0.43 & 0.50 \\
Training course & 0.04 & 0.21 & 0.06 & 0.23 & 0.03 & 0.17 \\
Training on-job & 0.20 & 0.40 & 0.25 & 0.43 & 0.14 & 0.35 \\
Training self-taught & 0.75 & 0.43 & 0.70 & 0.46 & 0.82 & 0.38 \\
Wageworker & 0.05 & 0.23 & 0.07 & 0.26 & 0.03 & 0.17 \\
Own-account & 0.81 & 0.40 & 0.81 & 0.39 & 0.80 & 0.40 \\
Micro-enterprise & 0.14 & 0.35 & 0.12 & 0.33 & 0.16 & 0.37 \\
Observations & 223 & & 126 & & 97 & \\
& & & & & & \\
\hline
\end{tabular}

Source: Author's elaboration based on project survey data.

Notes: * figures are from the random sample where $\mathrm{N}=164, \mathrm{n}$ (Nairobi) is 96 and $\mathrm{n}$ (Kisumu) is 68

** median daily earning is USD 7.4 which is often a more accurate measure of income than mean when SD is high. Median daily earning is USD 6.7 for Nairobi and USD 7.9 for Kisumu.

Table 7.1 also reveals that only 27 percent are making individual contributions to formal social insurance schemes, that is, health insurance and pension, slightly higher in Kisumu (29 percent) compared to Nairobi (26 percent). The differences in contribution patterns are partly tied to incomes as discussed later. Women constitute 55 percent of the micro-traders, which is consistent with national results showing that a large share (60.7 percent) of unlicensed enterprises in wholesale and retail are owned by females (KNBS, 2016).

The average age of micro-traders is 37 , most of them are married (63 percent), and the majority have obtained formal education with 43 percent having completed secondary education. These findings are consistent with the national findings showing that a higher share of business operators (59.7 percent) under wholesale and retail had completed secondary education, followed by 30.7 percent who had primary education, and 9.6 percent who had no education (KNBS, 2016). With respect to skills, a large segment of micro-traders (75 percent) are self-taught, 20 percent learnt the skills while on the job, and the remaining 5 percent attended a training course. These findings illustrate that micro-trading requires no specific vocational training or only a brief initiation. 


\section{Income and assets}

Table 7.1 shows that the average daily earnings of micro-traders is USD 11; however, the median value (USD 7.4) offers a fairer representation due to some high earners in the sample pulling up the mean. In terms of region, Kisumu traders have higher incomes than Nairobi traders, and this difference is statistically significant. Likely explanations for this difference are: (i) some food products sold in Kisumu such as fish are likely to fetch high returns, (ii) as mentioned earlier, Kisumu county government permits traders to transact businesses in designated commercial streets, including moving where there is human traffic (near bus terminus) after $5 \mathrm{pm}$ and this is likely to improve profits, and (iii) the Kisumu sample composed of fewer wage-workers who have lower mean earnings (USD 3.36) compared to micro-enterprise owners (USD 19.89). This difference in income may partly explain why the proportion of those making contributions to formal insurance schemes was higher in Kisumu (29 percent) than in Nairobi (26 percent).

In terms of assets, Table 7.1 reveals that 23 percent of workers owned a plot of land and/or a house. Region-wise, a higher share of Kisumu traders (32 percent) own assets compared to Nairobi traders (17 percent), and this difference is statistically significant at the 99-percent confidence level. This is in accordance with Kisumu traders having higher incomes, and since assets may be used as collateral for loan applications, that explains the observed higher share of Kisumu traders (40 percent) applying for loans compared to Nairobi traders (33 percent).

\section{Work-related characteristics}

Table 7.1 reveals that most micro-traders ( 81 percent) are own-account workers, 14 percent are micro-enterprise owners, and only 5 percent are wage-workers. Since access to formal insurance benefits is tied to an employment relationship under ILO Convention No. 102 (WIEGO, 2019), our findings suggest the need to rethink the design of employment-related protection since most traders are not in a standard employment relationship. Most traders operate informally since they are neither registered nor licensed. The rest of businesses are partly informal, that is, registered only or licensed, supporting the view of informality as a continuum and not a dualistic sector.

While Kenya seeks to formalize the informal economy through registration and licensing, our findings show that an overwhelming majority of the microtraders (97 percent) have not applied for business registration. Since the law prohibits one from operating without a license, many pay a fee ranging from between KES 30 and KES 50 to urban authority officials to occupy their trading locations ( 54 percent), to prevent harassment (33 percent) or eviction ( 9 percent) from those locations.

In terms of region, most Kisumu traders pay official fees compared to 10 percent of Nairobi traders as shown in Figure 7.1. Thus, the activities of traders are more regulated in Kisumu, whereas most of the Nairobi traders (60 percent) 


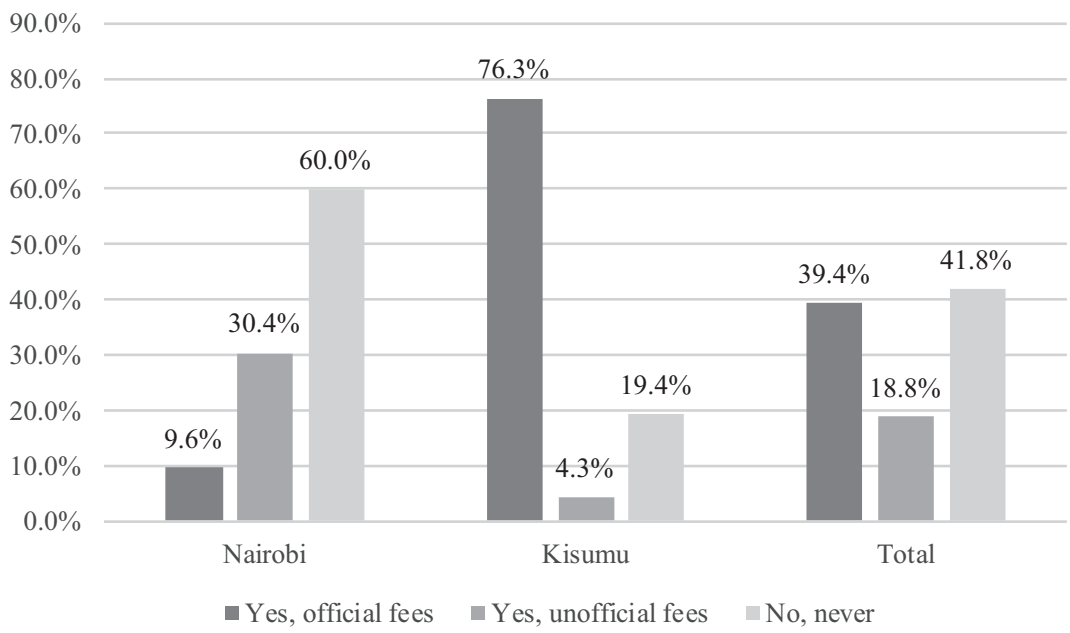

Figure 7.1 Distribution on payment of fee by city.

Source: Author's elaboration based on project survey data.

do not pay any fees which can perhaps be partly explained by the Nairobi City County Government's decision to abolish fees charged on small-scale traders as was noted earlier.

\section{Reasons for engagement in micro-trade}

Most micro-traders (73 percent) operated close to their homes at a distance of under $5 \mathrm{~km}$. Analysis of distance covered by gender revealed that a higher share of women (79 percent) lived closer to their homes than men ( 65 percent). This indicates that women are more likely to take up jobs closer to their homes due to their reproductive roles, which also explains why a larger share of micro-traders are women.

Table 7.1 shows that Kisumu has a higher share of micro-traders who are locally born (4l percent) compared to Nairobi with 18 percent indicating that a large share of micro-traders migrated to the capital in search of employment opportunities. In contrast, since Kisumu city is a smaller city (with fewer employment opportunities compared to Nairobi), it is likely that those traders that were not born in Kisumu city migrated from rural parts of Kisumu county or nearby counties.

Dualists (Hart, 1973) argue that people migrating to urban areas but do not find formal work are likely to find employment in the informal economy. Our finding partly confirms this claim as noted by many micro-traders. Figure 7.2 shows that the two main reasons were "money is good" and "I could not find anything to do". On the second response, the top two reasons were "I prefer to be my own boss" and "I could not find anything to do". The prevalence of 


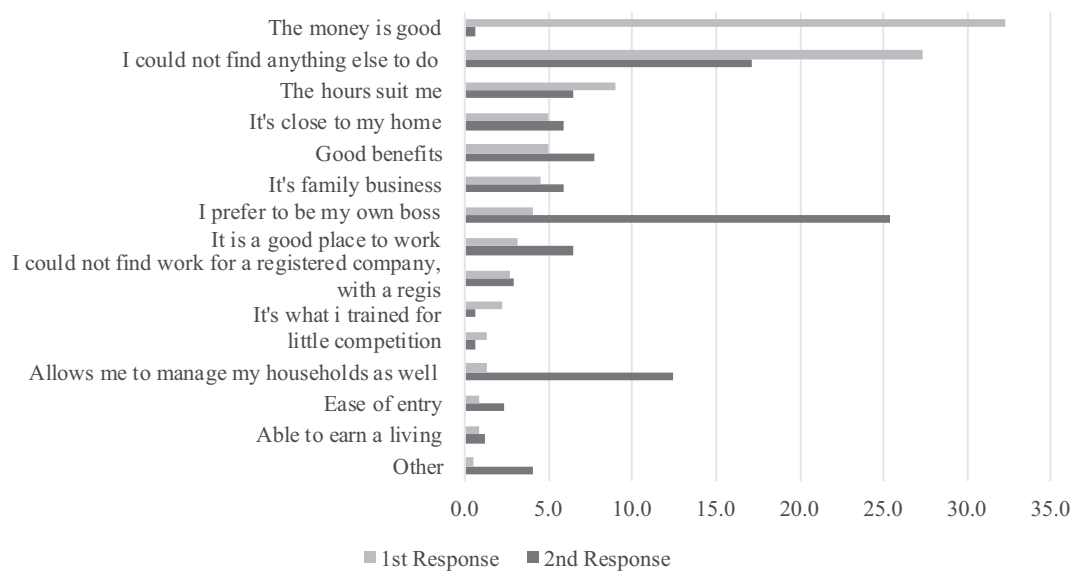

Figure 7.2 Why did you choose this line of business? Source: Author's elaboration based on project survey data.

"I could not find anything to do" is evidence that people are getting into microtrading due to lack of employment opportunities in the formal economy. The reasons "money is good" and "I prefer to be my own boss" lend support to the voluntarist school of thought (e.g. Maloney, 2004) who argue that some people willingly choose to work in the informal economy because they perceive opportunities such as higher incomes but not because they are forced by circumstances. The share of those who indicated that 'money is good' was higher among micro-enterprise owners (48 percent) than own-account workers (31 percent) and paid workers (17 percent). This finding suggests that job satisfaction is positively correlated with earnings since micro-enterprise owners tend to have higher incomes compared to own-account workers and paid workers. The next section outlines the challenges faced by micro-traders to establish the need for social protection.

\section{Micro-traders' challenges}

Micro-traders face many challenges, which include harassment by city officials (24 percent), lack of shelter (22 percent), inadequate capital or high prices of raw materials (14 percent), reduced customers or sales (11 percent), among others as shown in Table 7.2. On the second challenge, problems tied to lack of shelter topped the list as shown in second column in Table 7.2. The harassment complaint confirms the conflict between traders and city authorities highlighting the need for voice and representation. The challenges of heat and weather conditions are tied to the nature of trading locations and legislative requirements. Micro-traders are prohibited from making permanent shelters forcing some to operate from open spaces and others to move with their wares from place to 
Table 7.2 Describe the two key challenges/threats/problems you face in your work

\begin{tabular}{lcc}
\hline & $\begin{array}{c}\text { Challenge 1 } \\
\text { (Percent) }\end{array}$ & $\begin{array}{c}\text { Challenge 2 } \\
\text { (Percent) }\end{array}$ \\
\hline Reduced customers/low sales & 11.2 & 9.4 \\
Harassment from city officials & 23.8 & 3.6 \\
customer debts & 2.7 & 1.8 \\
High prices of goods/lack of raw materials/inadequate & 13.9 & 8.5 \\
$\quad$ capital & 5.4 & 3.1 \\
Competition from other vendors & 22.0 & 14.3 \\
Harsh weather, for example, rain, cold/no shelter & 10.8 & 4.9 \\
Losses due to perishable/seasonal products & 1.3 & - \\
Forced to close shop due to parental obligation/ & & \\
$\quad$ sickness & 1.8 & 4.0 \\
Lack of storage facilities/no business location & 4.9 & 47.1 \\
No challenge & 0.4 & 1.8 \\
Insecurity/theft & 0.9 & 0.9 \\
Air pollution & 0.9 & - \\
Waste disposal & - & 0.9 \\
Lack/inadequate clean water & 100.0 & 100.0 \\
Total (N = 223) & & \\
\hline
\end{tabular}

Source: Author's elaboration based on project survey data.

place. Those located along roads are predisposed to vehicle emissions which negatively impact on their health. These findings reveal that micro-traders are operating in harsh conditions, and their challenges require policy attention and support in terms of access to social protection.

The goal of OHS is to foster a safe work environment. However, this framework has traditionally been applied to formal employment, with marginal attention to IWs. Most micro-traders (76 percent) have never been injured at their workplace or suffered from a work-related illness, while 24 percent reported having suffered from work-related injury or sickness, and of those, the majority ( 65 percent) were from the Nairobi region. This suggests that micro-trading carries little risk of personal injury from use of tools at work. However, some of their trade locations are prone to harassment, crime, and air pollution. Harassment which emanates from the conflict between traders and city authority officials is often violent, especially within the CBD (Racaud, Kago \& Owuor, 2018).

Our results show that most of those who suffered from work-related injury/ sickness incurred medical expenses (42 out of 54) and of those the majority paid from out of pocket ( 28 out of 54 ). The rest were paid for by relatives, employer, and colleagues. Only a few of those who reported having suffered from workrelated injury/sickness used health insurance cover.

Slightly above half (28 of 54) continued working despite injury or workrelated illness. The rest stayed away from work for less than a month and only a few for more than a month. This finding suggests that micro-trading does not present serious OHS risks forcing micro-traders to abandon work, while others are forced to work because of lack of options. 


\section{Micro-trader associations}

This section focuses on associations formed by micro-traders with a view to showing if they enable access to formal and informal social protection measures.

\section{Association landscape}

Although there are many types of associations, the dominant associations among micro-traders are $\operatorname{chama}{ }^{5}$ (67 percent), worker associations (22 percent), and others (11 percent) as shown in Table 7.3. In terms of region, Nairobi has a higher share of chamas ( 79 percent) compared to Kisumu ( 54 percent), and a significant share of worker associations are in Kisumu (31 percent) compared to Nairobi (14 percent).

Table 7.3 reveals that the share of association members having formal health insurance is higher (49 percent) compared to the sample average (39 percent in Table 7.1). It also reveals a higher share of association members as contributors to formal insurance schemes (35 percent) compared to the sample mean of 29 percent indicating a link between belonging to associations and access to formal insurance. In terms of region, health insurance coverage is higher in Nairobi (54 percent) than in Kisumu (45 percent), and this is tied to the fact that 16.7 percent of Nairobi traders indicated that they were under their spouse's cover compared to only 9.3 percent Kisumu traders.

Table 7.3 Key worker characteristics, association members

\begin{tabular}{|c|c|c|c|c|c|c|}
\hline & \multicolumn{2}{|l|}{$A l l$} & \multicolumn{2}{|c|}{ Nairobi } & \multicolumn{2}{|c|}{ Kisumu } \\
\hline & Mean & $S D$ & Mean & $S D$ & Mean & $S D$ \\
\hline $\begin{array}{l}\text { Formal insurance } \\
\text { enrolment }\end{array}$ & 0.35 & 0.48 & 0.31 & 0.47 & 0.40 & 0.49 \\
\hline $\begin{array}{l}\text { Health Insurance } \\
\text { coverage }\end{array}$ & 0.49 & 0.50 & 0.54 & 0.50 & 0.45 & 0.50 \\
\hline \multicolumn{7}{|l|}{ Association type } \\
\hline Sacco/vicoba/chama & 0.67 & 0.47 & 0.79 & 0.41 & 0.54 & 0.50 \\
\hline Worker association & 0.22 & 0.42 & 0.14 & 0.35 & 0.31 & 0.47 \\
\hline Other association & 0.11 & 0.31 & 0.07 & 0.26 & 0.15 & 0.36 \\
\hline \multicolumn{7}{|l|}{ Benefit type } \\
\hline Work-related & 0.15 & 0.36 & 0.14 & 0.35 & 0.15 & 0.36 \\
\hline Social cushioning & 0.01 & 0.09 & 0.00 & 0.00 & 0.02 & 0.12 \\
\hline Voice & 0.01 & 0.12 & 0.00 & 0.00 & 0.03 & 0.17 \\
\hline Loans & 0.83 & 0.38 & 0.86 & 0.35 & 0.80 & 0.40 \\
\hline Barriers & 0.65 & 0.48 & 0.65 & 0.48 & 0.65 & 0.48 \\
\hline Fee & 0.74 & 0.44 & 0.63 & 0.49 & 0.86 & 0.35 \\
\hline Observations & 136 & & 71 & & 65 & \\
\hline
\end{tabular}

Source: Author's elaboration based on project survey data. 
Trader associations in Kenya can be categorized into two: grassroot level associations and umbrella associations which function either at the national or county level. Grassroot associations are quite small comprising at least 10 members and mainly address issues relating to welfare of members such as sickness, funerals, school fee payment, and purchase of household goods and offer opportunities for savings and access to loans. On the other hand, umbrella associations have large membership comprising a network of grassroot associations, whose main role is advocacy and representation.

The next section provides brief histories of three cases of associations. The first case is an example of a national umbrella association playing a unique role of voice and representation, while the second is an example of an association focusing on asset creation as the basis for organizing. The last case is an example of a grassroot association.

\section{Association histories}

The Kenya National Alliance of Street Vendors and Informal Traders (KENASVIT) $^{6}$ is an umbrella association formed in 2005 to represent and voice concerns of street vendors, hawkers, and market traders in Kenya. It brings together 20 urban affiliates from across the country. Its activities are guided by a constitution which outlines leadership structure and objects of the association. Its leaders are drawn from the chapters and elected for a term of four years.

The KENASVIT Chairperson sits as a member of MSEA as illustrated in the following quote: “...my role in the board is to advise the government on issues pertaining to MSE and to "encourage Kenyans to be entrepreneurs" (KII, Nairobi).

KENASVIT has about 400,000 mostly female members. Registration for groups is KES 5,000 , and individual members pay monthly subscription fees of KES 20 through their groups. KENASVIT advocates for rights of traders to use public space. This role is more pronounced due to regular conflicts between traders and city authorities. In 2014, for example, when traders in Kisumu were evicted from Oile market, KENASVIT leaders engaged Kisumu County officials, but their efforts did not prevent the eviction. KENSAVIT Chair noted that there are many competing associations of traders preventing them from having a unified voice. Traders tend to be more united during crises such as evictions. In the absence of conflict, support of umbrella associations declines as expressed in this quote: “...when members are being harassed, that is when they look for me. They will call you at any time when their businesses are being threatened. However, when things go back to normal, they relax".

While protest is a common approach to defending rights, KENASVIT employs other strategies such as negotiation, as observed in this quote, “...negotiation allows for give and take. You do not stand your ground”. Although traders, through this approach, have obtained rights to use public spaces, trading locations are not allocated to them permanently but temporary as they might be required to vacate if need be. 
Through networking with other trader associations, KENASVIT has been able to prevent eviction of traders in other areas of Kisumu. Some of KENAVIT partners are local grassroot organizations (e.g. Muungano wa Wana vijiji), national NGOs (Pamoja Trust and Kenya Land Alliance), public agencies, for example, the Institute for Development Studies (IDS), MSEA, and transnational organizations, for example, StreetNet International, Women in Informal Employment Globalizing and Organizing (WIEGO), and Unitarian Universalist Service Committee (UUSC), and other international development partners (e.g. DFID and Oxfam). These partners play a crucial role providing financial and technical support.

Micro and Small Enterprise Leaders' Summit (MSEL) ${ }^{7}$ was registered in 2013 and has over 60,000 members but only 30,000 are active. Most active members were noted to be female $(20,000)$. Half of MSEL members are informal traders. To become a member, a group must pay a registration fee of KES 3,000 , while an individual must pay a fee of KES 1,000. The association has members in all the 17 constituencies of Nairobi City County and holds election yearly. The term of elected officials is renewable every year. However, there is no limit to the number of years an official can serve in MSEL.

Prior to registration, MSEL existed as a movement. Currently, it is an umbrella association of groups and Community Based Organizations (CBOs). Membership is open not only to groups and CBOs but also to individuals. MSEL not only performs the role of voice and representation but also empowers members economically and socially. Members comprise self-employed workers. In terms of gender, most of the MSEL members are women. Age-wise, MSEL is dominated by youth.

MSEL operates Savings and Credit Cooperatives (SACCOs) ${ }^{8}$ in each constituency of Nairobi. To become a SACCO member, one must register with KES 500. However, membership to the SACCOs is voluntary. According to MSEL Chairperson, the purpose of establishing SACCOs was to encourage members to save regularly and own assets, hence be able to access loans from financial institutions. Members of SACCOs contribute weekly as subscription fee to service loans. The association had saved up to KES 30 million, which enabled it to access a loan of KES 25 million to buy land for building houses for SACCO members.

MSEL is working with other institutions at the local, national, and international level. At the international level, MSEL in collaboration with county government participated in one of the United Nation (UN) meetings on green economy to promote tree planting. At the national level, cage fish farmers participated in the blue economy conference which took place early 2019.

MSEL also advocates for the rights of traders. It advocated for mobile traders to trade in Eastleigh after the business community of Eastleigh had opposed trade in front of their premises. This resulted in a policy providing space on the third floor of a commercial building for mobile traders. In addition, MSEL spearheaded the establishment of Eastleigh Hawkers Association (EHA).

Apindi Smart Friends (ASF) ${ }^{9}$ is a grassroot association based in Kisumu, established in 2013, and is registered with the Ministry of Gender, Children and 
Social Development which registered chamas. It comprises 30 members but only half are active and committed to making regular contributions to the group. In terms of gender distribution, eight of the active members are males, while seven are females. The group is open to all, as expressed by the Chairperson, “... anyone can join. We have street traders, teachers, transport workers, family and friends joining the group. But majority of members operate from the street and contribute daily fees to the County government". The group mobilizes resources through savings and issues loans to members at a small interest rate. It also has an emergency fund which members contribute KES 50 daily and an income generating activity involving hiring of chairs to other groups for meetings. The group cushions members in case a member falls sick and is admitted to hospital through contributions. Each member is required to contribute KES 300, and very few members of the group have access to formal social protection services.

\section{Social protection services}

This section uses Devereux and Sabates-Wheeler (2004) classification of social protection measures as an analytical framework for understanding services offered by associations and formal insurance schemes.

\section{Preventive measures}

According to Devereux and Sabates-Wheeler, preventive social protection measures are measures which seek to avert deprivation. Examples of such measures include health insurance and pension. Services offered by the state or by associations that seek to avert financial stress attributed to eventualities such as sickness, death, or loss of employment fall within this category.

Access to formal social insurance:

The two main avenues for accessing health insurance and pension services offered by the state are through the NHIF and the NSSF schemes. Participation of IWs in these schemes is voluntary, whereas, for formal workers, it is mandatory. In the absence of an employer, IWs must self-enrol and make monthly contributions to the schemes to access services. As earlier mentioned, only 27 percent contributed regularly to a formal scheme and of these most contributed to a health insurance scheme (50 out of 61 ), but only a few contributed to a pension scheme (6 out of 61 ) and other insurance schemes ( 5 out of 61 ); a clear indication that health is a priority for traders rather than saving for retirement.

Figure 7.3 shows that the two top causes for low enrolment in formal insurance schemes are cost and lack of interest. This finding suggest that most micro-traders find it difficult to pay monthly premiums because of irregular, low incomes and the premium cost which is considered too high.

A probe of poor enrolment in formal insurance schemes with association members revealed that, for the NSSF scheme, inadequate, or lack of, information is the main reason for poor enrolment. Most participants mistook the NSSF scheme to be a product for formal workers. Others noted that they had lost trust 


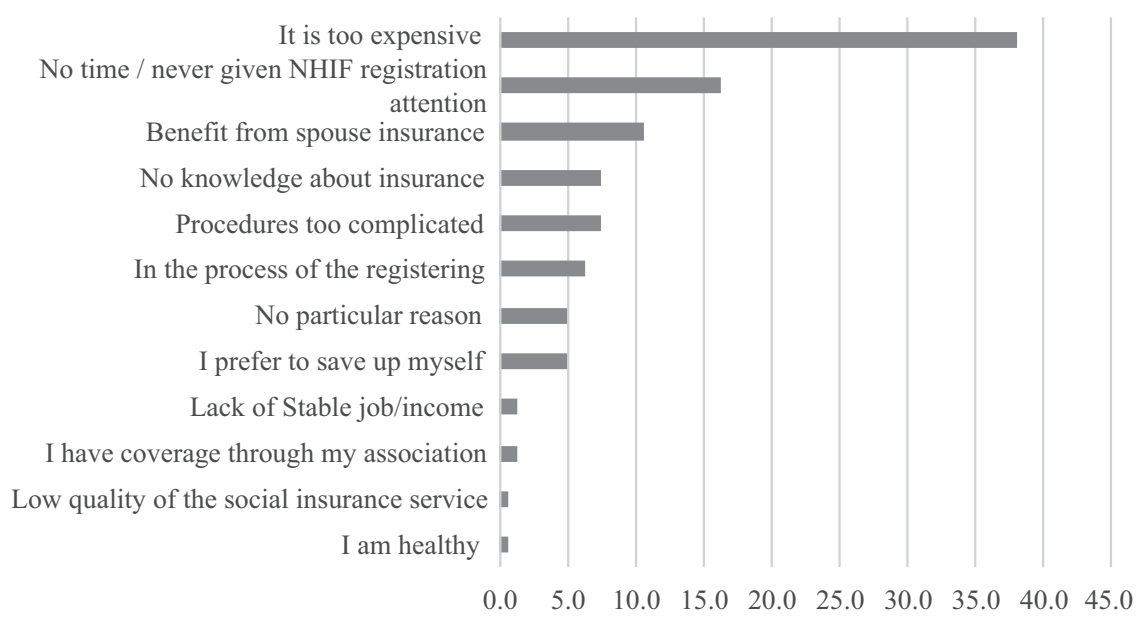

Figure 7.3 Reasons for not enrolling.

Source: Author's elaboration based on project survey data.

in the NSSF scheme due to corruption. One informant indicated that pension was not a priority for them as quoted, "...we are businesspeople. We find it difficult to save for retirement when you still have stock to buy" (KII, Nairobi). This quote shows the pension schemes as unattractive and unsuited to micro-traders' needs.

Regarding the NHIF, some indicated that the monthly premium of KES 500 was too high, while others found the registration processes as cumbersome because it requires them to take time off from work to register which means loss of income. The perception of insurance as a 'bad omen' was also an obstacle to enrolment as is noted in the following quote:

...some people do not join because they believe insurance comes with a bad omen. There is Deputy Commissioner who is my friend who believes that having an insurance brings bad omen. I know a number of people who share the same belief.

(KII, Nairobi)

Almost all micro-traders (95 percent) knew about the NHIF scheme but not necessarily how it works. Interestingly, almost half (48 percent) came to know about the scheme from their social networks such as family, friends, and from their associations. This shows that social networks are a crucial channel in the spread of information. The rest knew about the NHIF from media (29 percent), interaction with NHIF officials ( 10 percent), or interaction with hospital staff (5 percent) or from previous employment ( 8 percent). 
Of the 39 percent in Table 7.1 that are members of the NHIF scheme, many (42 out of 87 ) registered themselves, some (30 out of 87 ) registered through their spouse, and others (15 out of 87 ) registered themselves and their spouses. This finding shows that enrolment is not only an individual decision but also a social decision.

Among the non-members of NHIF scheme, a few (25 out of 136) had previously been members of the scheme. When these were asked to give reasons for leaving the scheme, their reasons were 'it was too expensive' (60 percent), 'loss of formal employment' (20 percent), disappointed with the scheme benefit (12 percent), benefit from spouse (4 percent), and no reason (4 percent). During discussion with micro-traders and KIIs, this issue was probed. Box 7.1 confirms the above reasons:

The above quotes reveal that default decisions are influenced by factors related to socio-economic characteristics such as low and irregular incomes and factors related to service provision such as cost of premium and cumbersome procedures. This suggests the need to redesign the NHIF scheme to make it attractive

\section{Box 7.1 Reasons for default}

...I had an accident and could not pay for NHIF. I paid the fine. The payment of the fine of KES 250 is a problem (FGD, Kisumu).

...sometimes we wonder, what is the use of having the card? I am forced to pay for medicine that is worth more than KES 700, yet I have a card (FGD Nairobi).

...the deadline for remitting the money is 9 th of every month...try paying (via m-pesa) on 7 th or 8 th, and it will not reflect in the system (FGD, Nairobi).

...there is no client service in public hospitals. They mistreat us. Nurses are very bad. The services are poor. The machines are sometimes not working. However, the private hospitals (where we pay cash) treat us very well (FGD, Nairobi).

...I work in town, but I have registered to access hospital where I live. If something happens to me in town, I must go to where I registered to receive services. If I am sick in the rural areas, I must travel to Nairobi to receive services (KII, Nairobi).

...it is difficult for NHIF members to change hospitals. Changes can only be made on the months of June and December (FGD, Nairobi).

...if you are sick and you want approval from NHIF, the process is hard. They take you to and fro. For MRI clearance you are sent to headquarters (at Upperhill) to get approval (FGD, Nairobi). 


\section{Raphael Indimuli}

in terms of cost and to adjust the premium payment plan to the realities of informal work characterized by low and irregular incomes and long working hours.

Informal social protection measures:

Discussions with association members revealed that most associations had set up structures (e.g. rules and social funds) to cushion members from risks associated to sickness, death, and loss of employment as is noted:

...we contribute towards welfare. If you are sick or have any problem such as funeral, lacking school fees. The group discusses and agrees to give you some money.

(FGD, Kisumu)

Members mobilized resources in forms of savings on a daily, weekly, or monthly basis. This practice was anchored in a group constitution and members who defied it were subject to some form of sanctions. Almost half of association members (45 percent) in the survey contacted their associations to access the services offered by the associations, mostly services related to welfare and benefits (92 percent). Some groups offered some form of 'maternity leave' to nursing mothers as noted by this quote, “...new mothers are given 2 months maternity leave which entails not attending meetings" (FGD, Kisumu). Other groups assist women in managing their businesses while on maternity to ensure that they have an income and are consistent in payment of contributions to the group. Some other groups of women contribute a given amount of money to take care of expenses of the nursing mothers.

Although groups cushioned members during sickness, it was noted that not all kinds of illness were covered by groups but only those that lead to hospital admission or those that prevent members from working. Some groups could visit sick member at home or in hospital while others contribute to offset hospital bills on admission of their member. However, the assistance given to members was noted to be one-off hence most groups had no provision for prolonged hospital admission.

\section{Promotive measures}

Promotive social protection measures are those measures which seek to enhance incomes (Devereux \& Sabates-Wheeler, 2004). One can argue that services offered by groups such as loans and training fall under promotive measures. Most of those belonging to associations (83 percent) reported savings and loans as the most important benefit of being in an association as shown in Table 7.3. The ability to issue emergency loans and flexible payment plans are some of the features of associations as is noted:

Recently a member lost goods and had a loan which was to be paid next Friday, but we extended and allowed him to pay later. 
Associations can provide loans to their members through regular savings. It is from this pool of savings that members can access loans at a small interest rate, often at 10 percent compared to Kenya bank lending rate which stood at averagely 13.1 percent in 2018 (TradingEconomics, 2020). However, unlike banks or any other formal financial institutions which issue loans, the interest from loans offered by some associations is shared between members at the end of a certain period, as observed: “...we give loans but interest will be divided later" (FGD, Kisumu).

Yet, like formal institutions, late payment of loans attracts penalty or fines. This requirement does not discourage members from taking loans because income from fines is also shared amongst members. Some associations guard against defaulting by requiring a member requesting a loan to have a certain number of other members guarantee the loan.

\section{Transformative measures}

Using the Devereux and Sabates-Wheeler framework, one can argue that grassroot associations are structured to offer preventive and promotive social protection, while umbrella associations tend to offer transformative social protection which relate to representation and voice. In Table 7.3, a small proportion (1.5 percent) mentioned voice and representation as an important benefit of belonging to an association. This is because association members were largely sampled from grassroot type of associations.

The importance of voice and representation can be seen in the context of conflicts between city authorities and traders. As mentioned earlier, many of the umbrella associations have emerged to express grievances of traders as highlighted below:

NISCOF was formed to reduce harassment and eviction of micro traders by city authorities. The Association negotiated for establishment of Muthurwa market for micro traders.

(FGD, Nairobi)

Although strikes are a common way to express grievances in formal employment, only 17 percent of micro-traders had participated in a strike/protest. Since our research establishes that problems relating to the work environment are substantial, this finding suggests that protests may be an ineffective approach or that traders are employing other approaches to voice grievance. Other methods used to engage with the state include negotiation or soliciting help from political actors who perceive them as vote banks because of their large numbers. The main reason for engagement with the state is to improve their working conditions, as was noted in the following quote:

...we engage the County mostly on conditions of the market. Market must have shades and toilets. During rainy and sunny weather, traders need to 


\section{Raphael Indimuli}

be protected from heat and rains. They also need to be provided with clean water because we cannot afford to buy water all the time. Regarding mobile traders, our Association has been negotiating for stoppage of harassment.

(KII, Nairobi)

\section{Application of the power resource approach}

This sub-section adopts the Power Resource Approach (PRA) as outlined in more detail in Chapter 1 of this book as a lens to identify power resources available to associations and how they are applied to achieve desired outcomes (Schmalz, Ludwig \& Webster, 2018). Using the PRA lens, one can argue that micro-traders lack structural power which relates to the position of workers in the economic system. Structural power rests on the power to cause disruption (disruptive power) to such an extent that it interrupts productive use of capital. As mentioned, most association members ( 83 percent) have never participated in a strike or street blockage. This suggests that trader associations are not adequately organized to capitalize on such power; otherwise, they would make use of their large numbers.

Umbrella associations command greater associational power than grassroot associations. This is influenced by large membership, better organization, and leadership structure which enable them to play the role of voice and representation more effectively. In contrast, grassroot associations are often small, and their basis for organizing revolves around welfare and business. They are often inward-looking with conditions which keep others from joining. This trait makes it difficult to network with other associations.

While umbrella associations are more inclined to command associational power, they are weakened by inactive participation of members which reduces their material resources necessary for collective engagement with other actors. However, resource barriers can be reduced by forming alliances with other actors as similar to KENASVIT which has established networks with IDS Nairobi and donors to access material and technical support. MSEL, although it has a strong financial base, is inward-looking because it is organized around the creation of assets for members with hardly any alliances with other trader associations.

With respect to institutional power, umbrella associations are more inclined to appropriate this power when they have strong associational and societal power. Institutional power relates to the ability to use institutions such as legislation to advance own interests. Kenyan legislation has recently created structures that provide a platform for IWs to participate in making decisions that affect microtraders mentioned by the chair of KENASVIT, who is a member of the board of MSEA. He uses his position to advance the interests of micro-traders and informal workers in general.

Societal power refers to power arising from cooperation with other social groups and organizations. There are two sources of societal power: coalition power and discursive power. Coalition power refers to having networks with other social actors at one's disposal and being able to activate these powers for 
mobilization and campaigns, while discursive power is the ability to interpret or frame burning issues to achieve societal power. Umbrella associations possess more of coalition power (as opposed to discursive power), especially those with interaction with other actors including politicians. An example is KENAVIT which has made alliances with local actors, transnational trader organizations, donors, and the state. Through these networks, it has been able to influence policy and acquire the resources necessary for lobbying. Lindell (2010) points out that the alliance between KENASVIT and Kenya Land Alliance was formed to voice concern on access to land from which IWs derive their livelihoods.

Although relations with politicians may grant societal power to associations to advance own interests, this power resource is time-limited because it can only be tapped when politicians are in position of power (KII, Nairobi). Political alliances potentially weaken group solidarity because of divergent voices within the group as is pointed out in following quote:

...every of our groups has a political friend. The unity that we once had has weakened. Politics has affected our membership. It has become a big problem.

(KII, Nairobi)

The above discussion shows that PRA is useful to understand how power is formed or utilized by associations in voice and representation. However, there is difficulty in extending the PRA framework to grassroot associations whose focus is more inward-looking on welfare and business issues. The following section discusses some of the challenges of trader associations.

\section{Associations' challenges}

Trader associations face challenges of member participation which may limit their ability to deliver services to their members. Most associations have inactive' members who do not submit regular contributions. Inactiveness is most pronounced among umbrella associations who have a broader mandate of advocacy and lobbying and who need resources to mobilize. Thus, when more members fail to contribute, it affects activities of the association unless there is external support from donors, as is illustrated in the following quote:

...the office was closed last year because of members were not remitting the subscription fees. We were unable to pay the rent.

(KII, Nairobi)

While there is power in collective engagement, sustaining solidarity between members or among groups is a challenge to some associations. One association noted that some members default on payment of loans. They choose to exit their association after receiving a loan (FGD, Kisumu). One informant confirmed that an association which he belonged to collapsed when two members took a 


\section{Raphael Indimuli}

loan and disappeared (KII, Kisumu). While loan protection insurance exists a type of insurance designed to cover loan repayment and protect the insured from default - one participant pointed out that available products in the market are not suited for workers in the informal economy (KII, Kisumu). The above discussions show that weaknesses within groups may affect the abilities of the groups to deliver services (including providing link to formal insurance) to their members and to some extent lead to the 'demise' of groups.

\section{Discussion}

\section{Access to associations}

\section{Entry conditions}

Most trader associations are guided by constitutions that allow them to achieve their objectives. Although trader associations tend to offer a wide scope of social protection services (compared to formal insurance schemes) that could improve the livelihoods and welfare of their members, Table 7.3 shows that most trader associations (65 percent) have rules or conditions that prevent others from becoming members of these associations. Membership or entry to these associations depended on the nature of work (56 percent), geographic location (19 percent), gender (12 percent), social or family relations (5.8 percent), special conditions such as disability ( 2 percent), and others (5.9 percent). ${ }^{10}$

The findings were confirmed through observation and through discussion with association members and their leaders. Some associations comprised of women only while others were organized based on special needs, that is, persons with disabilities, persons suffering from HIV/AIDS, etc. Yet, others were based on the nature of work. Other than conditions, one can argue that membership fees and regular contributions may hinder entry to associations especially if these are high and incomes uncertain. This lock-out because of criteria reduces chances of accessing social protection from associations and further exposes non-members to poverty and need for social assistance.

\section{Comparison between members and non-members}

This section looks at the extent to which association membership is associated with social protection. It uses the list of relevant variables shown in Table 7.1 to compare association members with non-members with the object of identifying statistically significant differences between them. Table 7.4 shows that association members are significantly more likely to enrol or be covered by formal insurance schemes than non-members. As for gender, there is a higher share of men among non-members than among members suggesting that women are more likely to join associations. Association members tend to be older compared to non-members and are more likely to be married. In terms of 
Table 7.4 Differences in key workers characteristics by association member status

\begin{tabular}{lcccc}
\hline & Not Member & Member & $\begin{array}{c}\text { Difference } \\
(N-U)\end{array}$ & t-Value \\
& & & & \\
\hline $\begin{array}{l}\text { Formal insurance enrolment } \\
\quad \text { (health/pension) }\end{array}$ & 0.15 & 0.35 & -0.20 & $-3.40^{* * *}$ \\
Health Insurance coverage & 0.23 & 0.49 & -0.26 & $-4.05^{* * *}$ \\
Nairobi & 0.63 & 0.52 & 0.11 & 1.62 \\
Kisumu & 0.37 & 0.48 & -0.11 & -1.62 \\
Gender (male = 1) & 0.60 & 0.35 & 0.24 & $3.68^{* * *}$ \\
Married & 0.55 & 0.68 & -0.13 & $-2.00^{* *}$ \\
Local & 0.28 & 0.29 & -0.01 & -0.18 \\
Age & 33.16 & 38.88 & -5.71 & $-3.94^{* * *}$ \\
Mean daily earnings (current & 7.94 & 13.16 & -5.21 & $-3.35^{* * *}$ \\
$\quad$ USD) & & & & \\
Assets (house and/or land) & 0.18 & 0.26 & -0.08 & -1.39 \\
Primary incomplete & 0.18 & 0.15 & 0.04 & 0.73 \\
Primary complete & 0.33 & 0.45 & -0.12 & $-1.71^{*}$ \\
Secondary or above & 0.48 & 0.40 & 0.08 & 1.15 \\
Training course & 0.02 & 0.06 & -0.04 & -1.26 \\
Training on job & 0.22 & 0.19 & 0.03 & 0.49 \\
Self-taught & 0.76 & 0.75 & 0.01 & 0.15 \\
Wageworker & 0.14 & 0.00 & 0.14 & $4.64^{* * *}$ \\
Own-account & 0.84 & 0.79 & 0.05 & 0.96 \\
Micro-business & 0.02 & 0.21 & -0.19 & $-4.14^{* * *}$ \\
Observations & 223 & & & \\
\hline
\end{tabular}

Source: Author's elaboration based on project survey data.

Notes: ${ }^{* *}<0.01,{ }^{* *}<0.05,{ }^{*}<0.1$.

incomes, members of associations are more likely to have higher incomes compared to non-members. This matches the finding that members are more likely to be micro-enterprise owners who have higher earnings, whereas non-members are dominantly wage-workers with lower earnings. In sum, the findings suggest that members of associations are more likely to be older married women who are micro-enterprise owners with higher earnings and more likely to enrol themselves and their families in formal insurance schemes.

The findings thus suggest that associations play a crucial role in the adoption of formal insurance among their members. Discussion with association members and their leaders confirms this finding. Some associations had indeed played a crucial role in registration of members to NHIF as evidenced in the following quote:

...All members of my group are registered for NHIF and are contributing KES 200 every month through the group. Every week, the group takes a sum of KES 7000 to the NHIF. if a member is unable to pay the KES 200 the group takes the money from the members' savings and pays for him or her. The member who is being paid for is considered to have a debt of the group which he or she must pay.

(FGD, Kisumu) 
The above quote not only shows how some associations encourage enrolment but also shows how a group can prevent default among their members. Apart from this example, there are no other cases of associations paying contributions for their members. Nairobi Informal Sector Confederation (NISCOF) which is an umbrella association made efforts to register their members in the NHIF scheme but experienced a challenge paying premium as a group and opted for each member to make their own payment.

\section{Comparison between the enrolled and the non-enrolled members of formal insurance schemes}

This section examines the differences between the enrolled and the nonenrolled members of formal SI schemes. In line with Table 7.4, Table 7.5 shows that there is a higher share of association members enrolled in formal insurance schemes compared to non-members. The formal insurance members are more likely to be married, of a higher age, and are more likely to belong to workerrelated associations offering loans. They are also more likely to be better off

Table 7.5 Differences in key workers characteristics by social insurance enrolment

\begin{tabular}{|c|c|c|c|c|}
\hline & $\begin{array}{l}\text { No Social } \\
\text { Protection }\end{array}$ & $\begin{array}{l}\text { Social } \\
\text { Protection }\end{array}$ & $\begin{array}{l}\text { Difference } \\
(N-U)\end{array}$ & t-Value \\
\hline Association member & 0.54 & 0.79 & -0.24 & $-3.40 * * *$ \\
\hline Sacco/vicoba/chama & 0.40 & 0.43 & -0.02 & -0.34 \\
\hline Work related association & 0.09 & 0.26 & -0.18 & $-3.51^{* * *}$ \\
\hline Women/youth/religious & 0.06 & 0.10 & -0.04 & -1.14 \\
\hline Work-related & 0.09 & 0.08 & 0.01 & 0.25 \\
\hline Loans & 0.44 & 0.67 & -0.23 & $-3.08 * * *$ \\
\hline Voice and representation & 0.01 & 0.02 & -0.01 & -0.72 \\
\hline Social cushioning & 0.00 & 0.02 & -0.02 & -1.64 \\
\hline Nairobi & 0.57 & 0.54 & 0.03 & 0.44 \\
\hline Kisumu & 0.43 & 0.46 & -0.03 & -0.44 \\
\hline Male & 0.42 & 0.52 & -0.10 & -1.40 \\
\hline Married & 0.57 & 0.80 & -0.24 & $-3.31^{* * *}$ \\
\hline Local & 0.26 & 0.34 & -0.09 & -1.26 \\
\hline Age & 35.54 & 39.59 & -4.05 & -2.50 ** \\
\hline Mean daily earnings (current USD) & 9.74 & 14.81 & -5.07 & $-2.96 * * *$ \\
\hline Assets (house and/or land) & 0.20 & 0.31 & -0.11 & $-1.70^{*}$ \\
\hline Primary incomplete & 0.19 & 0.10 & 0.09 & 1.57 \\
\hline Primary complete & 0.42 & 0.36 & 0.06 & 0.80 \\
\hline Secondary or above & 0.40 & 0.54 & -0.15 & $-1.97 * *$ \\
\hline Training course & 0.04 & 0.07 & -0.03 & -0.92 \\
\hline Training on job & 0.17 & 0.28 & -0.11 & $-1.76^{*}$ \\
\hline Self-taught & 0.79 & 0.66 & 0.13 & $2.09^{* *}$ \\
\hline Wageworker & 0.07 & 0.02 & 0.05 & 1.52 \\
\hline Own-account & 0.84 & 0.72 & 0.12 & $2.00 * *$ \\
\hline Micro-business & 0.09 & 0.26 & -0.17 & $-3.33^{* * *}$ \\
\hline Observations & 223 & & & \\
\hline
\end{tabular}

Source: Author's elaboration based on project survey data.

Notes: ${ }^{* *}=0.01,{ }^{* *}=0.05,{ }^{*}=0.1$. 
in terms of education, with higher incomes and assets compared to those not enrolled in formal insurance schemes. When it comes to employment status, formal insurance members are more likely to be micro-enterprise owners, while own-account are less likely to enrol in formal insurance schemes This is to be expected, as was noted earlier that micro-enterprise owners had higher mean daily earnings of USD 20 compared to own-account workers with a mean daily earning of USD 10.

\section{Conclusion}

This chapter has examined the socio-economic characteristics of traders, the characteristics of associations including their challenges, and the extent to which they influence access to formal and informal social protection services. It has shown that many micro-traders still do not have access to health insurance and pensions offered by the state. It has also revealed that health cover is more important to traders than pension cover and that reasons for not signing up (or defaulting) are influenced by factors related to socio-economic characteristics such as low and irregular incomes and factors related to service provision such as cost of premium and cumbersome procedures. This suggests the need to redesign the NHIF scheme to make it attractive in terms of cost and to adjust the premium payment plan to the realities of informal work characterized by low and irregular incomes and long working hours.

The low uptake of formal insurance among IWs also begs the question of how non-enrolled members of formal insurance schemes cope without insurance and whether there are any other existing models for provision of social insurance to IWs. This chapter shows that trader associations have developed their own forms of social protection to support themselves, albeit not adequate in terms of meeting all needs. Using the Devereux and Sabates-Wheeler framework, this chapter has shown that social protection models of associations are designed to avert risks and shocks touching on associational life and livelihoods (preventive social protection), are useful in resource mobilization, as well as, in averting risks and shocks that threaten their livelihoods through voice and representation (transformative social protection) and through offering timely loans and training to members (promotive). However, these associations have weaknesses which affects the delivery of social protection. One main weakness of grassroot level associations is that most of them are small and are guided by regulations that restrict membership thus locking others out. Due to their small size, their resources are limited to meeting immediate needs.

This chapter has also shown that a higher share of association members enrols in formal insurance schemes than non-members. Indeed, there are some associations which enabled their members to access formal health insurance through provision of information and necessary support including making of regular payments.

Although the PRA framework reveals that there is strength in coming together to overcome challenges in the sector, this chapter has shown that most of 
the existing grassroot associations are 'inward-looking' which limits them from forming alliances with other associations. Furthermore, umbrella associations are mainly driven to action in cases of conflicts between micro-traders and city authorities. A few cases of active engagement are made possible through support of external institutions and actors, including politicians who provide resources needed for collective organizing and technical support.

\section{Notes}

1 Micro-trading here means activities of a person who owns or operates microenterprises with maximum employees and persons employed in such enterprises.

2 The average USD to KES rate used throughout the chapter is KES 101.2, rate from June 2018 to December 2018.

3 'Jua kali' is a Swahili word meaning 'hot sun'. The term reveals that informal activities are conducted in hot sun.

4 In addition, the UAC Act establishes a Board to manage the affairs of cities and town.

5 'Chama' is Kiswahili for groups formed by individuals with common objectives providing services like loans and savings, including welfare services.

6 This information is based on an interview with current KENASVIT Chairperson and with leader of Kisumu Informal Trader Economic Support (KITES).

7 This information is derived from interview with a representative of the Association.

8 SACCO activities are regulated under SACCO Societies Act, 2018.

9 Information was obtained from the Chairperson of the group.

10 On the second response, geographic location was the main condition (53.1 percent), followed by gender (37.1 percent), and others.

\section{References}

Brown, A. (2006) Challenging street livelihoods. In: Brown, A. (ed.) Contested space: Street trading, public space and livelihoods in developing cities. Warwickshire, ITDG Publishing, pp. 3-15.

Chen, M., Roever, S. \& Skinner, C. (2016) Editorial: Urban livelihoods: Reframing theory and policy. Environment and Urbanization. 28 (2), 331-342. Available from: doi:10.1177/0956247816662405.

Devereux, S. \& Sabates-Wheeler, R. (2004) Transformative social protection. IDS Working Paper 232. Brighton, Institute of Development Studies.

DN (17 October 2017) Sonko abolishes charges for city small-scale traders. Daily Nation. Available from: https://www.nation.co.ke/kenya/news/ sonko-abolishes-charges-for-city-small-scale-traders--458052.

Hart, K. (1973) Informal income opportunities and urban employment in Ghana. The Journal of Modern African Studies. 11 (1), 61-89.

ILO (1972) Employment, incomes and equity: A strategy of increasing productive employment in Kenya. Geneva, International Labour Office.

ILO (2002) Report VI, Decent work and the informal economy, Sixth item on the agenda. In: International Labour Organization. International Labour Conference 90 th Session. Geneva, International Labour Office.

ILO (2017) World employment and social outlook: Trends 2017. International Labour Organization. Geneva, International Labour Office. 
KNBS (2016) Micro, small and medium (MSME) establishment survey: Basic report 2016. Nairobi, Kenya National Bureau of Statistics.

KNBS (2018) Kenya integrated household budget survey 2015/2016. Nairobi, Kenya National Bureau of Statistics.

Lindell, I. (ed.) (2010) Africa's informal workers: Collective agency, alliances and transnational organizing in urban Africa. London, Zed Publications.

Maloney, W.F. (2004) Informality revisited. World Development. 33 (7), 1159-1178.

Mitullah, W.V. (2003) Street vending in African cities: A synthesis of empirical findings from Kenya, Cote D'Ivoire, Ghana, Zimbabwe, Uganda and South Africa. Washington, D.C., World Bank.

NCLR (2019) Urban and cities (amended) act. Nairobi, National Council for Law Reporting.

Racaud, S., Kago, J. \& Owuor, S. (2018) Introduction: Contested street: Informal street vending and its contradictions. Journal of Urban Research. 17-18. doi.org/10.4000/ articulo.3719

ROK (1992) Sessional paper no. 2 of 1992 on small enterprise and jua kali development in Kenya. Republic of Kenya. Nairobi, Government Printer.

ROK (2005) Draft sessional paper on development of micro and small enterprises for wealth and employment creation for poverty reduction. Republic of Kenya. Nairobi, Government Printer.

ROK (2019) The street vendors (protection of livelihood) senate bill, 2019. Republic of Kenya. Nairobi, Government Printer.

Schmalz, S., Ludwig, C. \& Webster, E. (2018) The power resources approach: Developments and challenges. Global Labour Journal. 9 (2), 113-134.

Skinner, C. (2008) Street trade in Africa: A review. Working Paper No 5. WIEGO.

TradingEconomics. (2020) Kenya bank lending rates. Available from: https:// tradingeconomics.com/kenya/bank-lending-rate.

WIEGO (2019) Extending social protection to informal Workers. WIEGO. Available from: https://www.wiego.org/publications/extending-social-protection-informal-workers. 